\title{
Installation of Attic Ventilation Fans in Residences
}

\author{
A RECORDED VOLUNTARY STANDARD OF THE TRADE
}

\section{COMMODITY STANDARDS}

Simplified Practice Recommendations and Commercial Standards are developed by manufacturers, distributors, and users in cooperation with the Commodity Standards Division of the Office of Industry and Commerce, Bureau of Foreign and Domestic Commerce, and with the National Bureau of Standards.

The purpose of Simplified Practice Recommendations is to eliminate avoidable waste through the establishment of standards of practice for stock sizes and varieties of specific commodities that currently are in general production and demand. The purpose of Commercial Standards is to establish standard methods of test, rating, certification, and labeling of commodities, and to provide uniform bases for fair competition.

The adoption and use of a Simplified Practice Recommendation or a Commercial Standard is voluntary. However, when reference to a Commercial Standard is made in contracts, labels, invoices, or advertising literature, the provisions of the standard are enforceable through usual legal channels as a part of the sales contract.

A Simplified Practice Recommendation or a Commercial Standard originates with the proponent industry. The sponsors may be manufacturers, distributors, or users of the specific product. One of these three elements of industry submits to the Commodity Standards Division the necessary data to be used as the basis for developing a standard of practice. The Division, by means of assembled conferences or letter referenda, or both, assists the sponsor group in arriving at a tentative standard of practice and thereafter refers it to the other elements of the same industry for approval or for constructive criticism that will be helnful in making any necessary adjustments. The regular procedure of the Division assures continuous servicing of each effective Simplified Practice Recommendation and Commercial Standard, through review and revision, whenever, in the opinion of the industry, changing conditions warrant such action. Simplified Practice Recommendations and Commercial Standards are printed and made available by the Department of Commerce through the Government Printing Office and the Department of Commerce field offices.

\section{UNITED STATES DEPARTMENT OF COMMERCE}

\section{Charles Sawyer, Secretary}




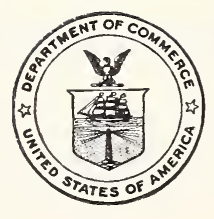

U. S. DEPARTMENT OF COMMERCE

Charles Sawyer, Secretary

BUREAU OF FOREIGN AND DOMESTIC

COMMERCE

Office of Industry and Commerce

H. B. McCoy, Director

IN COOPERATION WITH

NATIONAL BUREAU OF STANDARDS

E. U. CONDON, DIRECTOR 


\title{
Installation of Attic Ventilation Fans in Residences
}

\author{
[Effective from June 25, 1951]
}

\section{PURPOSE}

1.1 The purpose of this standard is to establish minimum specifications and to provide suggestions for the guidance of the installers and the users of attic ventilation fans, in order to assist the public in obtaining satisfactory and properly constructed attic-fan ventilation systems.

\section{SCOPE}

2.1 This standard covers definitions; general requirements and recommendations, including those for fan, plenum chamber, shutters, air change rate, and velocity through intake and discharge openings; and a uniform method for certifying compliance. Owing to the variety of structures to which this standard is applicable and to the variety of equipment, no effort has been made to confine this standard to specific structures or equipment.

\section{DEFINITIONS}

3.1 Attic ventilation fan types.-There are two types of attic fans covered by the provisions of this standard: (a) fans which discharge liorizontally, and (b) fans which discharge vertically.

3.1.1 Fans which discharge horizontally are usually installed in an outside wall if the attic is practically airtight, on the attic floor with a plenum chamber if the attic is unfinished, or in a penthouse if the building has a flat roof.

3.1.2 Fans which discharge vertically are generally installed in attics which are not airtight, or in cupolas on flat-roofed structures. No plenum chamber is required since the fan is mounted directly over the ceiling opening. Either automatic or manually operated shutters should be used to close the ceiling opening when the fan is not in use.

3.2 Manufacturer.-For the purpose of this standard, the manufacturer shall be the company or organization which evidences its responsibility to the purchaser by permanently affixing its name, address, or nationally registered trade-mark or trade name to the fan.

3.3 Installer.-The installer is the company, corporation, or individual who contracts for or installs the attic ventilating system.

\section{REQUIREMENTS}

4.1 Attic ventilation fan.-An attic ventilating fan shall be of a type designed for residential application and shall meet all the re- 
quirements and tests specified in Commercial Standard 178-51, Testing and Rating Ventilating Fans (Axial and Propeller Types).

4.2 Plenum chamber.-Plenum chambers shall be made of, or lined with, sound-deadening materials, and shall be so constructed as to be free from vibration.

4.3 Air change rate.--The installation shall provide for at least the minimum number of air changes per minute in the house indicated in figure 1 for its geographical location. The air change rate is to be based on the cubic feet of room volume in the space to be ventilated and usually does not include basement or attic space.

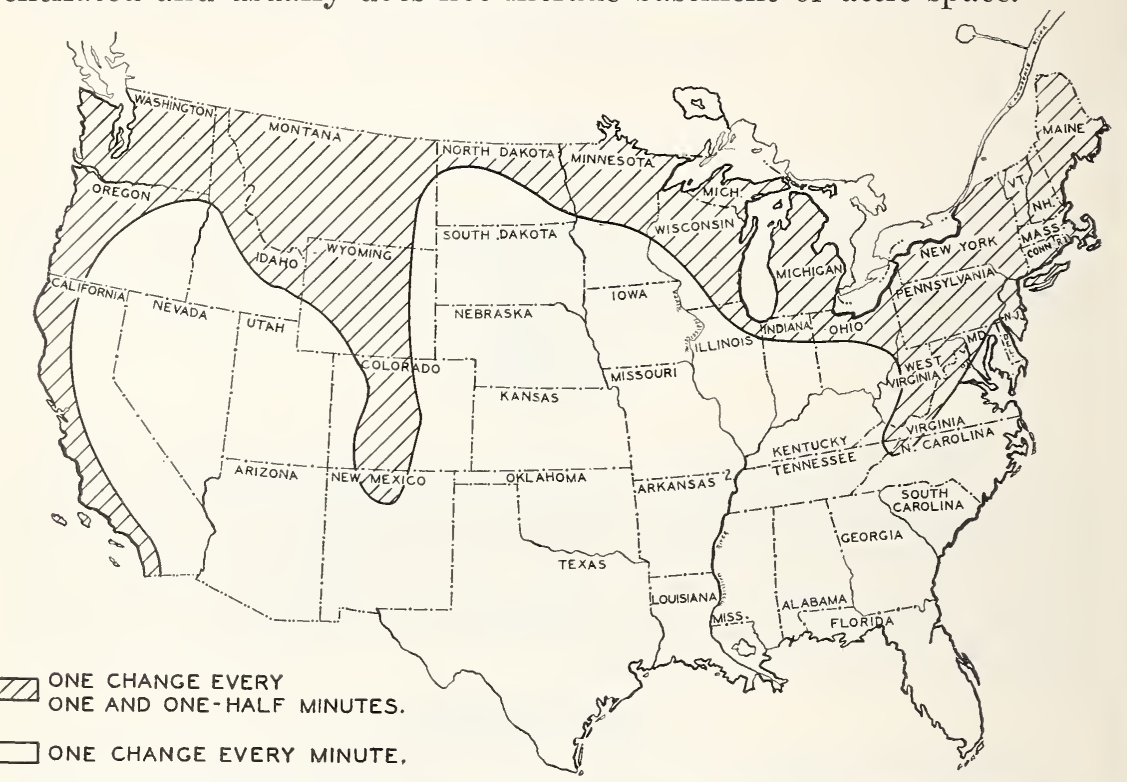

Figure 1. Minimum air changes recommended for attic ventilation systems.

4.4 Intake and discharge openings.-The size of the openings required depends on the type of fan installation. The three basic ways in which an attic fan may be installed are illustrated in figures 2,3 , and 4.

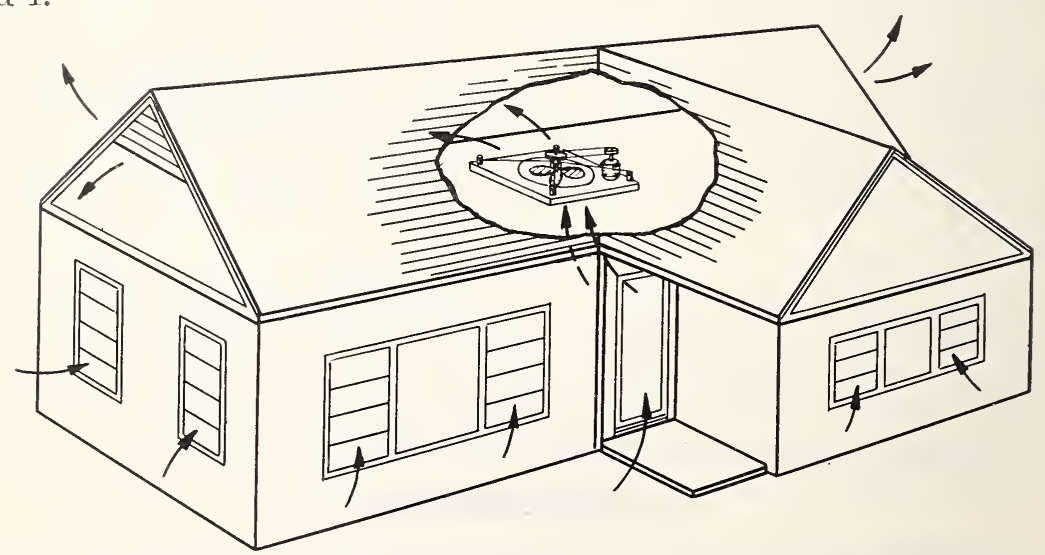

FIGURE 2. Vertical fan discharging into the attic space with fan mounted on attic floor. 


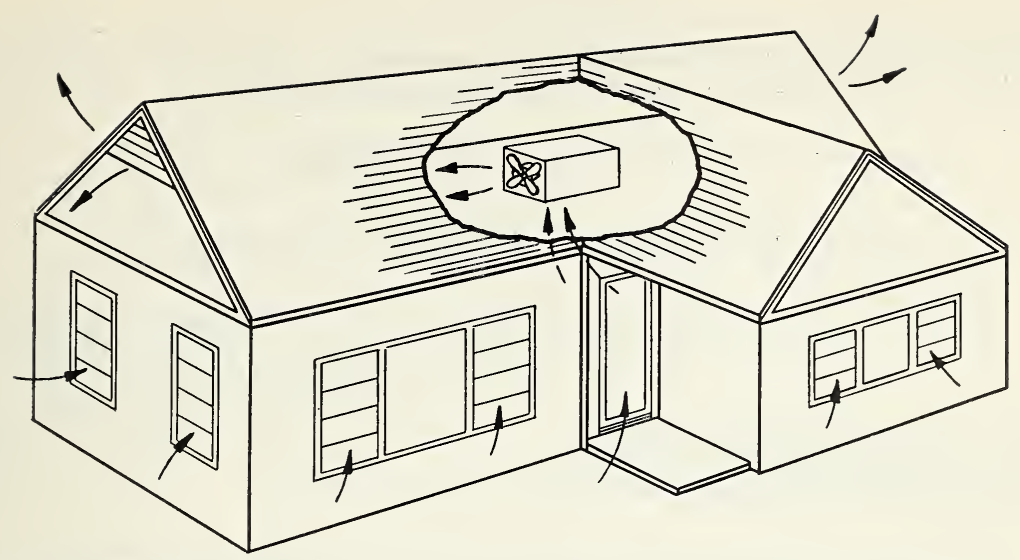

Figure 3. Fan mounted in a plenum chamber (suction box) in the attic.

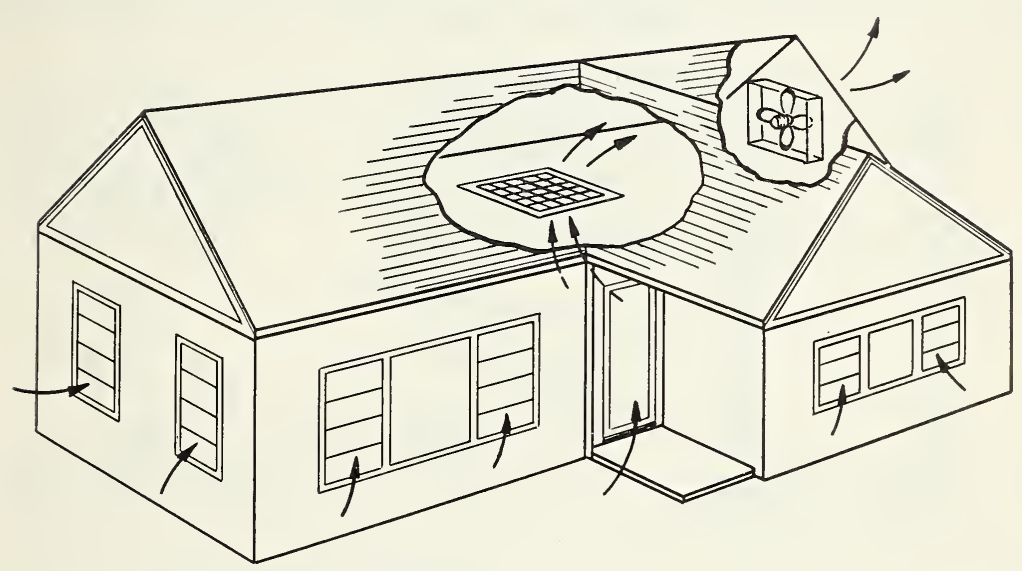

Figure 4. Fan mounted on the outside wall.

\subsubsection{Intake openings.}

4.4.1.1 Figure 2 type.-The intake opening area should be at least equal to that of the fan frame, allowing a reasonable margin for mounting, but the free area shall be not less than the square of the fan wheel diameter. If grilles are used the requirements given in paragraph 4.4.1.2 shall apply.

4.4.1.2 Figures 3 and 4 types.-Where grilles are used, the velocity through the free area of the grille shall range to a maximum of 1,000 feet per minute. ${ }^{1}$ Where ceiling shutters are used, the velocity through the free area of the shutter shall range to a maximum of 1,200 feet per minute. For optimum quietness and where mechanical and structural limitations do not interfere, lower velocities are desirable.

\subsubsection{Discharge openings.}

4.4.2.1 Figures $\mathscr{Q}$ and 3 types.-Table 1 is provided for the con-

${ }^{1}$ Velocity in feet per minute $=\frac{\mathrm{efm} \text { free delivery rating of fan }}{\text { free area of ceiling opening }}$. 
venient selection of the proper size of discharge opening. Figure 5 shows typical constructions of such openings. Gross discharge area is found from the free area by the following equation:

$$
\text { Gross area of opening }=\frac{\text { free area of opening }}{\text { percentage of free area of opening }} \text {. }
$$

TABLE 1.-Minimum gross outlet areas for discharge openings ${ }^{1}$

\begin{tabular}{l|r|r}
\hline \multicolumn{1}{c|}{ Type of opening } & $\begin{array}{c}\text { Minimum } \\
\text { free area }\end{array}$ & $\begin{array}{c}\text { Gross area per } \\
1,000 \text { cfm free } \\
\text { air delivery }\end{array}$ \\
\hline Wood louver backed with 1/2-in. hardware cloth & Percent \\
Metal louver backed with 1/2-in, hardware cloth & 40 & Square feet \\
Plain opening covered with 1/2-in. hardware cloth & 50 \\
Automatic or manual shutters mounted at a distance from fan (suction box \\
installation)
\end{tabular}

${ }^{1}$ Larger openings are desirable, since the air velocity will be lower, resulting in maximum quietness and economy of operation. Insect screen over openings is not recommended, but if used, add a minimum of 100 percent of the gross louver area. This may be done by: (a) Doubling the size of the louver or opening: (b) constructing a box-like frame behind the louver or opening, with a screened surface twice the area of the louver.
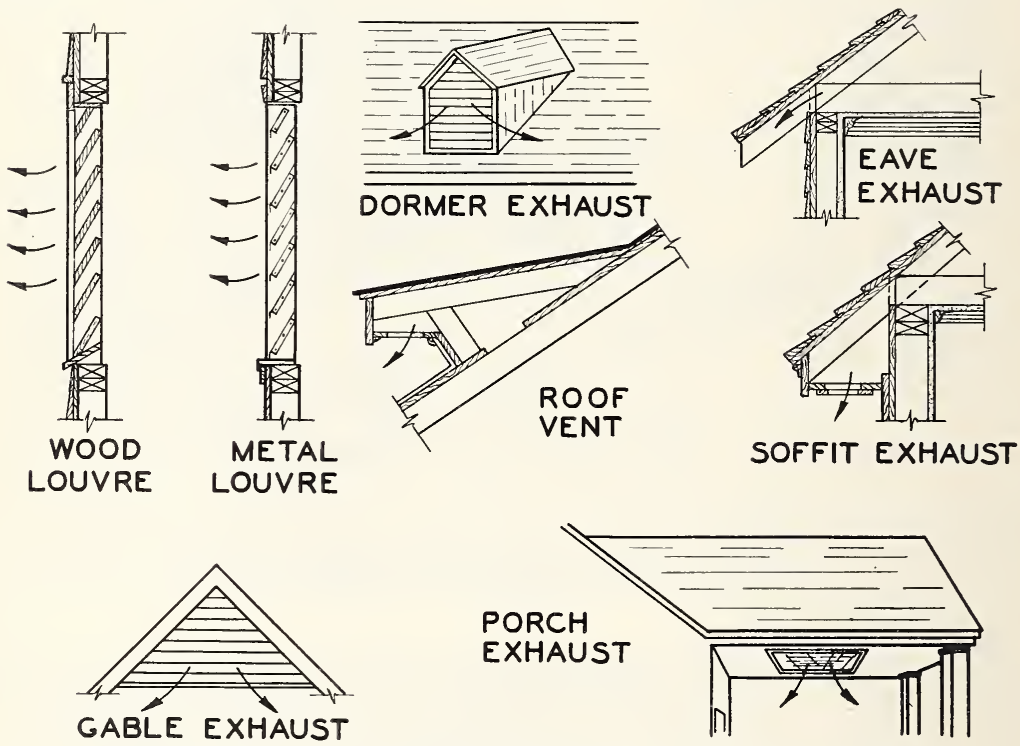

FIGURE 5. Typical constructions of discharge openings.

4.5 Electrical installation.-All electrical wiring shall be in accordance with State and local codes, and, if none exist, with the National Electrical Code.

4.6 Resilient mounting.-Some form of resilient mounting shall be provided between the fan proper and the building structure to minimize sound transmission.

4.7 Installation and operating instructions.-An adequate installation and service manual shall be made available by the manufacturer for the installer's use. A set of the manufacturer's operating instructions shall be furnished to the installer and he shall make them available to the owner or occupant of the house. 


\section{CERTIFICATION}

5.1 The following certificate, supplied by the manufacturer, shall be placed with each individual installation by the installer:

\section{INSTALLER'S CERTIFICATE}

This No.

attic ventilation fan at

(Brand or company name)

(Address)

has been installed in strict compliance with the requirements of Commercial Standard CS179-51, as developed by the trade under the procedure of the Commodity Standards Division, and issued by the U. S. Department of Commerce.

Signature
Company

\section{Date}

Note.-A thorough yearly inspection and lubrication is recommended.

\section{EFFECTIVE DATE}

6.1 Having been passed through the regular procedure of the Commodity Standards Division, and approved by the acceptors hereinafter listed, this commercial standard was issued by the United States Department of Commerce, effective from June 25, 1951.

\section{EDWIN W. ELY,}

Chief, Commodity Standards Division.

\section{HISTORY OF PROJECT}

On April 14, 1949, the Propeller Fan Manufacturers' Association, after consulting interested manufacturers, requested the cooperation of the National Bureau of Standards in the establishment of a commercial standard for the installation of attic ventilation fans in residences. A draft of the proposed standard was submitted by the Propeller Fan Manufacturers' Association on July 29, 1949, which was subsequently adjusted in accordance with suggestions of manufacturers and other interested organizations.

On June 27, 1950, the revised proposed commercial standard was circulated to the trade for advance comment. This draft was reviewed in detail by the Propeller Fan Manufacturers' Association on September 29, 1950, and adjusted to represent the composite views of all interested groups. The recommended standard was circulated to the industry for consideration and acceptance on March 1, 1951.

Following acceptance by a satisfactory majority, and in the absence of active valid opposition, an announcement was issued on May 25, 1951, that the standard had been accepted as a recorded voluntary standard of the trade, effective for new production from June 25, 1951.

Project Manager: H. A. Bonnet, Commodity Standards Division, Office of Industry and Commerce.

Technical Adviser: R. S. Dill, Building Technology Division, National Bureau of Standards. 
The following individuals comprise the membership of the standing committee, which is to review, prior to circulation for acceptance, revisions proposed to keep the standard abreast of progress. Comment concerning the standard and suggestions for revision may be addressed to any member of the committee or to the Commodity Standards Division, Office of Industry and Commerce, U. S. Department of Commerce, which acts as secretary for the committee.

\section{Manufacturers:}

Tom Byrd, Lau Blower Co., 2001 Home Avenue, Dayton, Ohio (chairman). M. L. Artken, Propellair Division, Robbins \& Myers, Inc., Springfield, Ohio.

Edw ARd Buddrus, Acme Equipment Co., 213 East Broadway, Muskogee, Okla.

E. W. Petersen, American Blower Corp., Detroit 32, Mich.

C. Espy REed, Reed Unit-Fans, Inc., 1001 Saint Charles Avenue, New Orleans 8, La.

\section{Distributors:}

M. O. Hollis, Raybro Electric Supplies, Inc., Tampa, Fla.

W. M. Schermes, Schermes Co., 220 West Seventy-second, Kansas City 5, Mo.

\section{Installers:}

E. F. Gaines, Home Conditioning Co., Tenth \& Moffet, Joplin, Mo.

T. J. OLIver, Oliver \& McClellan, Inc., 30 Church Street, New York 7, N. Y. JoHN L. UNDERWOod, John L. Underwood Co., Inc., 555 Whitehall SW., Atlanta 3, Ga.

\section{Consumers:}

R. K. Thulman, Housing and Home Finance Agency, $1626 \mathrm{~K}$ Street NW., Washington 25, D. C.

CARL E. Het.frich, 21 East York Street, Savannah, Ga. (representing American Institute of Architects). 


\section{ACCEPTANCE OF COMMERCIAL STANDARD}

If acceptance has not previously been filed, this sheet properly filled in, signed, and returned will provide for the recording of your organization as an acceptor of this commercial standard.

Commodity Standards Division,

Date

Office of Industry and Commerce,

U. S. Department of Commerce,

Washington 25, D. C.

Gentlemen :

We believe that the Commercial Standard 179-51 constitutes a useful standard of practice, and we individually plan to utilize it as far as practicable in the installation of attic ventilation fans in residences, with which we are directly concerned as a

$$
\begin{aligned}
& \text { producer }^{1} \\
& \text { distributor }^{1} \\
& \text { installer }^{1}
\end{aligned}
$$

purchaser $^{1}$

inspection agency ${ }^{1}$

We reserve the right to depart from it as we deem advisable.

We understand, of course, that only those articles which actually comply with the standard in all respects can be identified or labeled as conforming thereto.

Signature of authorized officer

(In ink)

(Kindly typewrite or print the following lines)

Name and title of above officer.

Organization

Street address

City, zone, and State.

1 Underscore which one. Please see that separate acceptances are filed for all subsidiary companies and affiliates which should be listed separately as acceptors. In the case of related interests, trade associations, trade papers, etc., desiring to record their general support, the words "General support" should be added after the signature. 


\section{TO THE ACCEPTOR}

The following statements answer the usual questions arising in connection with the acceptance and its significance :

1. Enforcement.-Commercial standards are commodity specifications, voluntarily established by mutual consent of those concerned. They present a common basis of understanding between the producer, distributor, and consumer and should not be confused with any plan of governmental regulation or control. The United States Department of Commerce has no regulatory power in the enforcement of their provisions, but since they represent the will of the interested groups as a whole, their provisions through usage soon become established as trade customs, and are made effective through incorporation into sales contracts by means of labels, invoices, and the like.

2. The acceptor's responsibitity.-The purpose of commercial standards is to establish, for specific commodities, nationally recognized grades or consumer criteria, and the benefits therefrom will be measurable in direct proportion to their general recognition and actual use. Instances will occur when it may be necessary to deviate from the standard, and the signing of an acceptance does not preclude such departures; however, such signature indicates an intention to follow the commercial standard, where practicable, in the production, distribution, or consumption of the article in question.

3. The Department's responsibitity.-The major function performed by the Department of Commerce in the voluntary establishment of commercial standards on a Nation-wide basis is fourfold: first, to act as an unbiased coordinator to bring all interested parties together for the mutually satisfactory adjustment of trade standards; second, to supply such assistance and advice as past experience with similar programs may suggest; third, to canvass and record the extent of acceptance and adherence to the standard on the part of producers, distributors, and users; and fourth, after acceptance, to publish and promulgate the standard for the information and guidance of buyers and sellers of the commodity.

4. Announcement and promulgation.- When the standard has been endorsed by a satisfactory majority of production or consumption in the absence of active, valid opposition, the success of the project is announced. If, however, in the opinion of the standing committee or of the Department of Commerce, the support of any standard is inadequate, the right is reserved to withhold promulgation and publication. 


\section{ACCEPTORS}

The organizations listed below have individually accepted this standard for use as far as practicable in the production, distribution, testing, purchase, use, or installation of attic ventilation fans in residences. In accepting the standard they reserved the right to depart from it as they individually deem advisable. It is expected that articles which actually comply with the requirements of this standard in all respects will be regularly identified or labeled as conforming thereto, and that purchasers will require such specific evidence of conformity.

\section{ASSOCIATIONS}

(General Support)

Propeller Fan Manufacturers' Association, Detroit, Mich.

\section{FIRMS AND OTHER INTERESTS}

Acme Equipment Co., Muskogee, Okla.

Aerovent Fan Co., Inc., Piqua, Ohio. (General support.)

Air Controls, Inc., Division of Cleveland Heater Co., Cleveland. Ohio.

Albert, Henry, Jr., \& Co., Inc., Pikesville, Md.

American Blower Corp., Dearborn, Mich.

American Coolair Corp. Jacksonville, Fla.

Bar-Brook Manufacturing Co., Inc., Shreveport, La.

Benefit Steel Furnace Co., Cincinnati, Ohio.

Booey, W. L., Co., Reading, Pa.

Bowser-Morner Testing Laboratories, Dayton, Ohio.

Buffalo Forge Co., Buffalo, N. Y.

Central of Georgia Railway Co., Savannah, Ga.

Champion Blower \& Forge Co., Lancaster,

Coastal Supply \& Chemical Co., Ridgewood, N. J.

Columbia Electrical Co., Kansas City, Mo. Commercial Testing \& Engineering Co., Chicago, Ill.

DeBothezat Fans Division, American Machine \& Metals, Inc., East Moline, Ill.

Electric Supply Co., Atlanta, Ga.

Garden City Fan Co., Chicago, Ili. (General support.)

Hardin Electric \& Supply, Inc., Salisbury,

N. C.
Hartzell Propeller Fan Co., Piqua, Ohio. (General support.)

Herman Nelson Division, American Air Filter Co., Inc., Moline, Ill. (General support.)

Holcomb \& Hoke Manufacturing Co., Inc., Indianapolis, Ind.

Home Conditioning Co., Joplin, Mo.

Hunt, Robert W.. Co., Chicago, Ill.

Hunter Fan \& "Ventilating Co., Memphis, Tenn.
Hunter, Morris, Inc., Richmond, Va.

Ilg Electric Ventilating Co., Chicago, Ill.

Iowa Sheet Metal Contractors, Inc., Des Moines, Iowa.

Lau Blower Co., Dayton, Ohio.

New York Testing Laboratories, Inc., New York, N. Y.

Newton-Stinchcomb Co., Baltimore, Md

Oliver \& McClellan, Inc., New York, N. Y.

Omaha Testing Laboratories, Omaha, Nebr.

Orman Wood \& Metal Products, Columbus, Ind.

Patzig Testing Laboratories, Des Moines, Iowa.

Peerless Electric Co., Warren, Ohio.

Pittsburgh Testing Laboratory, Pittsburgh, $\mathrm{Pa}$.

Plank Electric Co., Norwich, Conn.

Quietaire Corp., Houston, Tex.

Raybro Electric Supplies, Inc., Tampa, Fla. Redman Engineering Service, High Point, N. C.

Reed Ünit-Fans, Inc., New Orleans, La.

Rhodes Equipment Co., St. Louis, Mo.

Riverside Electric Co., Riverside, Ill.

Schermes Co., Kansas City, Mo.

Schwartz Appliances, Inc., Inwood, L. I., N. Y.

Sears, Roebuck \& Co., Chicago, Ill

Sonntag, J. H., \& Co., Dallas, Tex.

Sprouse, V. E., Co., Inc. Columbus Ind.

Standard Materials Co., Little Rock, Ark.

Stephenson Appliance Co., Raleigh, N. C.

Thompson \& Lichtner Co., Inc., Brookline, Mass.

Tour, Sam, \& Co., Inc., New York, N. Y.

Trane Co., La Crosse, Wis.

United States Testing Co., Inc., Hoboken, N. J.

Viking Air Conditioning Corp., Cleveland, Ohio. (General support.)

Weaver, G. B., \& Sons Electric Co., Salisbury, N. C.

Westendorf \& Co., Baltimore, Md.

Western Blower Co., Seattle, Wash.

Wing, L. J., Manufacturing Co., Linden, N. J.

\section{UNITED STATES GOVERNMENT}

Army, United States, Office of the Assistant Chief of Staff, Washington, D. C. 


\section{U. S. DEPARTMENT OF COMMERCE \\ Field Service}

Albuquerque, N. Mex., 203 W. Gold Are.

Atlanta 3, Ga., 50 Whitehall St. SW.

Baltimore 2, Md.. 200 E. Lexington St.

Boston, Mass., 40 Broad St.

Buffalo 3, N. Y., 117 Ellicott St.

Butte, Mont., 306 Federal Bldg.

Charleston 4, S. C., Area 2, Sergeant Jasper Bldg.

Cheyenne, Wyo., 410 Federal Office Bldg.

Chicago 1, I11., 221 N. La Salle St.

Cincinnati 2, Ohio, 105 W. Fourth St.

Cleveland 14, Ohio, 925 Euclid Ave.

Dallas 2, Tex., 1114 Commerce St.

Denver 2, Colo., 142 New Custom House

Detroit 26. Mich., 230 W. Fort St.

El Paso, Tex., 310 San Francisco St.

Hartford 1, Conn., 135 High St.

Houston 14. Tex., 602 Federal office $\mathrm{Bldg}$.

Jacksonville 1, Fla., 311 W. Monroe St.

Kansas City 6. Mo., 903 McGee St. Los Angeles 15, Calif., 112 W. Ninth St.

Louisville 2, Ky., 631 Federal Bldg. Memphis 3, Tenn., 229 Federal Pldg.
Miami 32, Fla., 36 NE. First St.

Milwaukee 2, Wis., 517 E. Wisconsin Ave.

Minneapolis 2, Minn., 607 Marquette Ave.

Mobile 10, Ala., 109-13 St. Joseph St.

New Orleans 12, La., 333 St. Charles Are.

New York 4, N. Y., 42 Broadway

Oklahoma City 2, Okla., 102 NW. Third st.

Omaha 2, Nebr., 1319 Farnam St.

Philadelphia 6, Pa., 1015 Chestnut St.

Phoenix, Ariz., 808 N. First St.

Pittsburgh 22, Pa., 717 Liberty Ave.

Portland 4, Oreg., 520 SW. Morrison St.

Providence 3, R. I., 327 Post Office Annex

Reno, Nev., 1479 Wells Ave.

Richmond 19, Va., 400 E. Main St. St. Louis 1, Mo., 1114 Market St.

Salt Lake City 1, Utah, 109 W. Second, South

San Francisco 2, Calif., 870 Market St.

Savamnah, Ga., 125-29 Bull St.

Seattle 4, Wash., 123 U. S. Court House. 